\title{
Microperforate hymen with infertility: rare case report
}

\author{
Aditi Jindal*, Rama Thakur \\ Department of Obstetrics and Gynecology, Indira Gandhi Medical College, Shimla, Himachal Pradesh, India
}

Received: 01 January 2018

Accepted: 31 January 2018

\section{*Correspondence:}

Dr. Aditi Jindal,

E-mail: aditijindal_18@yahoo.com

Copyright: (c) the author(s), publisher and licensee Medip Academy. This is an open-access article distributed under the terms of the Creative Commons Attribution Non-Commercial License, which permits unrestricted non-commercial use, distribution, and reproduction in any medium, provided the original work is properly cited.

\begin{abstract}
Female genital tract anomalies are rare but may have a serious impact on the reproductive health. Here we are going to discuss a rare case of pin point hymenal opening. Here the patient presented to us with primary infertility. She presented to a health care centre for the first time therefore she had never been examined. After all the initial investigations a diagnosis of micro perforate hymen was made. She was posted in OT for hymenectomy. She underwent excision of the hymenal tissue and the edges were sutured to the introitus to prevent reclosure of the hymen. She had an uneventful postoperative period. Patient was discharged after complete recovery at $5^{\text {th }}$ postoperative day. She resumed sexual functions 6 weeks after the surgery. These anomalies usually require surgical interventions. Correct surgical intervention is required for a better psychological and reproductive health.
\end{abstract}

Keywords: Imperforate hymen, Infertility, Pin point opening

\section{INTRODUCTION}

The female genital tract develops from the Mullerian ducts and the urogenital sinus. The genital tract anomalies may be closely related to the urinary tract and hence may be coexistent. Female genital tract abnormality is diverse and may remain asymptomatic or have varied presentations. These may include primary ammenorhea, infertility, recurrent pregnancy loss, repeated preterm labour.

Amongst them hymenal abnormalities are one of the female genital tract abnormalities. Incomplete degeneration of the central part of hymen may lead to hymenal abnormality. ${ }^{1}$ Hymenal anomalies may be obstructive or non-obstructive. It may be imperforate which may lead to hematocolpos and hematometra. These are the obstructive complications. They may be easier to diagnose since on examination there may be a tense bulging membrane seen at the introitus, and collection of blood in vagina and uterus on ultrasonography. Microperforate hymen is non obstructive, which may remain asymptomatic during the entire adolescence. They may not have any menstrual complaints. The exact incidence of this entity is unknown. We have come across only a few cases of microperforate hymen. Due to paucity of literature on this entity it is difficult to comment on the true incidence. It is usually an isolated anomaly but may be associated with bifid clitoris, duplicate ureter, hypoplastic kidneys, and other anorectal malformations. ${ }^{2}$

Here we present a rare case of micro perforate hymen where patient presented to us with primary infertility.

\section{CASE REPORT}

A 25-year nulligravida female, presented to the outpatient department with primary infertility. The couple did not give any other positive history. On obtaining obstetric history she has been married for 4 years and has been staying with her husband since then. She has not been able to conceive despite regular sexual intercourse. She attained menarche at the age of 14 years and has been having regular menstrual cycle with moderate flow. 
On examination, secondary sexual characters were corresponding to Tanner stage 4. On local examination there was membrane covering the vaginal introitus. Patient was re-examined during menstruation, when menstrual blood was seen trickling through a pinpoint opening (Figure 1).

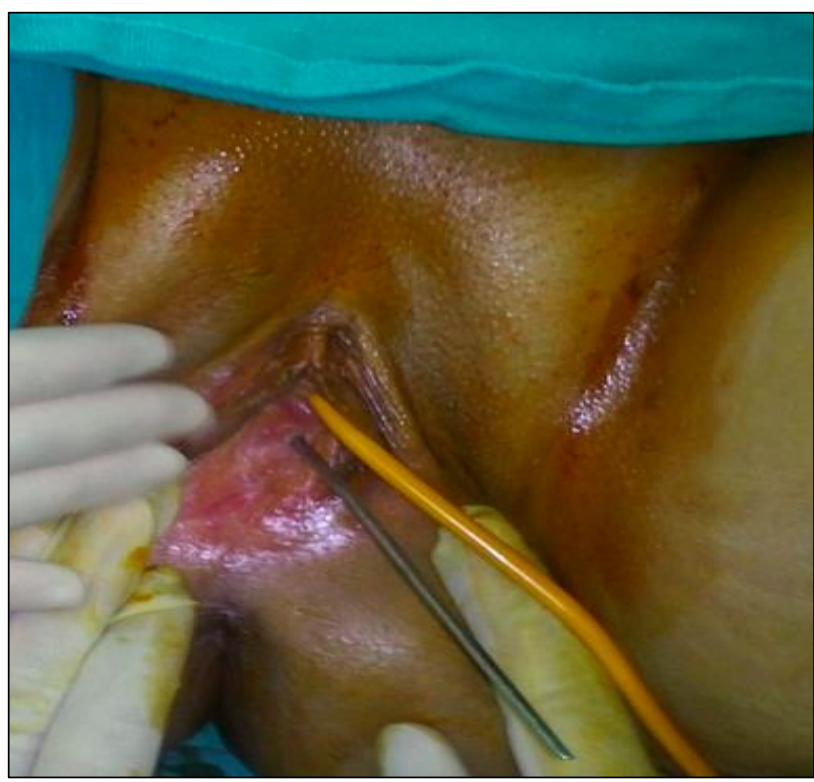

Figure 1: Thin pink membrane covering the introitus with pin point opening.

All her biochemical investigations were normal, and her ultrasonography was done which was normal.

\section{Treatment}

She was posted for excision of hymenal tissue in OT. To prevent reclosure the edges were sutured to the introitus. The patient had an uneventful postoperative period. She was discharged on the $5^{\text {th }}$ post-operative day.

\section{Follow up}

Patient was called for follow up after 6 weeks, but she did not come. Patient reported for follow up 7 months later at 8 weeks period of gestation.

\section{DISCUSSION}

A multitude of female congenital anomalies are uncommon. However, their impact on reproduction can be profound. Hymen marks the distal most extent of the vagina and the most proximal boundary of the vulvar vestibule Hymenal anomalies occurs if the genital tubercle fails to break down or rupture. ${ }^{3}$

Hymenal anomalies have varied presentations. Among these presentations include primary amenorrhoea, acute and chronic pelvic pain, abnormal vaginal bleeding, dysuria, pollakiuria or foul smelling vaginal discharge.
There may be repeated episodes of urinary tract infections. This may occur due to pooling of urine in the functional urogenital sinus and invasion into the urethra. Hence, when an adolescent girl presents with repeated episodes of urinary tract episodes they must be evaluated for genital tract anomalies. ${ }^{4}$

Microperforate hymen is a non-obstructive anomaly. This is usually a congenital anomaly and are present since birth. Very rare cases of spontaneous closure of hymen have been reported, after child abuse or previously operated for imperforate hymen where there may be spontaneous reclosure.

Other non-obstructive anomalies include septet and cribriform anomalies. Non-obstructive anomalies may be found incidentally on routine examination. Microperforate hymen (pinpoint opening in hymen) may present as vaginismus, difficulty in intercourse, infertility.

As in the case presented here our patient presented with infertility. There was delay in diagnosis because the patient approached health care facility late. Usually in case of hymen with pin hole opening it may permit passage of menstrual blood. ${ }^{5}$ There may be prolonged menstruation and may last for 4-7 days. The pinhole opening may allow passage of sperms also, therefore they have been rare case reports of pregnancy also. Microperforation may be difficult to visualise. To avoid this difficulty in diagnosis of micro perforate hymen, hence it is required to examine these patients at the time of menstruation.

The knowledge about this entity is required to make correct diagnosis. Lack of knowledge of this entity can cause diagnostic difficulty. ${ }^{6}$ Hence awareness about this rare entity may lead to early detection and improvement in patients' quality of life. ${ }^{7}$

Usually these congenital anomalies require surgical interventions. These surgical interventions may differ from each institute.

\section{CONCLUSION}

These anomalies usually require surgical interventions. Correct surgical intervention is required for a better psychological and reproductive health.

Funding: No funding sources

Conflict of interest: None declared

Ethical approval: Not required

\section{REFERENCES}

1. Guven D, Bakay K, Kuruoglu. Microperforate hymen and infertility: a rare case report. Open J Obstet Gynecol. 2012;2:287-8. 
2. Stephanie CT. Microperforate hymen and pyocolpos. J Paediatr Adolescent Gynaecol. 2017.

3. Kumar V, Kumar KV, Krishnamurthy KH, Kumar R. A rare case report of microperforate hymen with difficultty in penetration. J South Asian Federation Menopausal Societies. 2014;2(2):97-8.

4. Bhatnagar KP, Nettleton GS, Nakajima ST. Female genital anomalies affecting reproduction. Fertil Steril. 2002;78:899-915.

5. Bharathi KR, Vijayalkshmi S, Divya AN. An interesting rare case of spontaneous pregnancy with imperforate hymen and high transverse vaginal septum with bicornuate uterus. Int $\mathbf{J}$ Reprod Contracept Obstet Gynecol. 2017;6(1):341-3.

6. Goto K, Yoshinari H, Kotsuji F. Microperforate hymen in a primigravida in active labor: a case report. J Reprod Med. 2006;51(7):584-6.

7. Padhi M, Tripathy P, Sahu A. Microperforate hymen presenting with incomplete abortion: a case report. J Obstet Gynaecol Res. 2017;43(8):1353-5.

Cite this article as: Jindal A, Thakur R. Microperforate hymen with infertility: rare case report. Int J Reprod Contracept Obstet Gynecol 2018;7:1259-61. 